\title{
Peningkatan Aktivitas dan Hasil Belajar dengan Model Pembelajaran Vak Berbantu Media Tongkat Tokoh
}

\author{
Winda Rukmana ${ }^{1 *}$, Nyoto Hardjono ${ }^{2}$, Arlita Aryana $\mathrm{O}^{3}$
}

1,2,3 Pendidikan Guru Sekolah Dasar, Universitas Kristen Satya Wacana, Salatiga

\section{A R T I C L E I N F O}

Article history:

Received 19 May 2018

Received in revised form 25 June 2018

Accepted 10 July 2018

Available online 25 August 2018

Kata Kunci:

aktivitas belajar, hasil

belajar, model

pembelajaran VAK, tongkat

tokoh

Keywords:

learning activity, learning result, VAK teaching-

learning model, figure stick

\begin{abstract}
A B S T R A K
Tujuan penelitian ini yaitu meningkatkan aktivitas dan hasil belajar dengan menerapkan model pembelajaran VAK (Visual, Auditory, Kinestethic) berbantuan media tongkat tokoh. Penelitian Tindakan Kelas ini dilaksanakan di kelas 2 SD Negeri Salatiga 06 Kota Salatiga. Data yang dikumpulkan meliputi aktivitas dan hasil belajar, hasil observasi guru, hasil observasi siswa. Teknik pengumpulan data yang dilakukan pada penelitian ini adalah metode observasi, metode dokumentasi, dan metode tes. Penelitian ini dilaksanakan dalam dua siklus. Tiap siklus meliputi 4 (empat) tahap yaitu persiapan, penyampaian, pelatihan, dan penampilan hasil. Pada penelitian ini dikatakan berhasil apabila sekurang-kurangnya $80 \%$ siswa memperoleh nilai $\geq 75$. Hasil penelitian menunjukkan : (1) Skor aktivitas pra siklus di kelas 3 sebesar $72 \%$ dengan nilai rata-rata 73,50 dan skor ketuntasan belajar siswa pra siklus sebesar 75\% dengan nilai rata-rata 76,50; (2) Skor aktivitas siswa pada siklus I sebesar $70 \%$ dengan nilai rata-rata 76,20 dan pada siklus II sebesar 82,50\% dengan nilai rata-rata 82,40; (3) Ketuntasan belajar siswa pada siklus I sebesar $72,50 \%$ dengan nilai rata-rata 78,15 dan pada siklus II sebesar $83,50 \%$ dengan nilai rata-rata 85,25 . Dari data tersebut di atas jelas menunjukkan bahwa pada siklus I aktivitas dan hasil belajar belum sesuai harapan yang berarti indikator keberhasilan belum tercapai sedangkan pada siklus II aktivitas dan hasil belajar sudah sesuai harapan yang berarti indikator keberhasilan sudah tercapai.
\end{abstract}

A B S T R A C T

This research aims to improve the activity and the learning result by implementing teachinglearning model of VAK (Visual, Auditory, \& Kinestethic) and figure stick media, This Classroom Action Research was conducted in the class 2 of SD Negeri Salatiga 06, Salatiga. The obtained data comprised the activity and the learning result, the teacher-observation result, and the studentobservation result. The techniques of the data collection were observation, documentation, and test methods. This research was conducted in two cycles. Each cycle covers 4 (four) stages i.e. preparing, delivering, training, and evaluating. In this research, it can be concluded as successful if there is at least 80 percent of student total number gaining score $\geq 75$. The result of this research shows that: (1) the activity scores of the students in the pre-cycle on class 3 is about 72 percent with the mean of 73.5 and the mastery level of student learning in the pre-cycle is about 74.5 percent with the mean of 76.5 ; (2) the activity scores of the students in the cycle I is about 70 percent with the mean of 76.2 and the cycle II is about 82.5 percent with the mean of 82.4; (3) the mastery level of student learning in the cycle I is about 72.5 percent with the mean of 78.15 and in the cycle II is about 83.5 percent with the mean of 85.25. From the data aforementioned, it clearly shows that the activity and the learning result did not achieve the target in the cycle I meaning that the indicators of success were not fulfilled, while the activity and the learning result achieved the target in the cycle II meaning that the indicators of success were fulfilled. 


\section{Pendahuluan}

Pendidikan mempunyai peranan penting bagi kehidupan manusia dan salah satu investasi terpenting bagi suatu bangsa. Jika suatu bangsa ingin menjadi bangsa yang maju, maka hal pertama yang harus diperhatikan adalah bagaimana bangsa tersebut menjalankan pendidikan. Pendidikan sekolah dasar merupakan salah satu jenjang pendidikan yang ada di Indonesia dan merupakan pendidikan formal pertama yang dapat ditempuh dalam jangka waktu normal selama 6 tahun. Terkait dengan pelaksanaan program pendidikan di Indonesia, pemerintah terus berupaya untuk meningkatkan kualitas pendidikan secara menyeluruh. Tidak hanya pemerintah, seluruh komponen bangsa wajib berpartisipasi untuk mencerdaskan kehidupan bangsa. Hal tersebut sesuai dengan tujuan pendidikan nasional, sebagaimana tercantum dalam Undang-Undang Republik Indonesia Nomor 20 Tahun 2003 tentang Sistem Pendidikan Nasional pasal 3. Upaya pemerintah untuk meningkatkan kualitas pendidikan yaitu dengan adanya perbaikan Kurikulum yang diterapkan. Kurikulum yang baru diterapkan saat ini adalah Kurikulum 2013 yang berbasis kompetensi dengan mengunggulkan penggunaan pendekatan scientific dengan suatu proses ilmiah yang mengembangkan sikap, keterampilan dan pengetahuan siswa.

Pendidikan didukung oleh adanya kurikulum yang mengatur bagaimana pendidikan yang sewajarnya berjalan sesuai dengan tujuan dari pendidikan itu sendiri. Awalnya, Kurikulum 2013 ditetapkan dan dilaksanakan pada SD yang menjadi percontohan untuk SD lainnya disekitar lingkup wilayah, namun saat ini banyak SD yang mengikuti jejak SD percontohan karena tuntutan dari pemerintah yang menghendaki untuk mencetak generasi penerus yang kreatif, inovatif, dan berdedikasi tinggi. Hal itu dialami oleh SDN Salatiga 06 yang kami wawancarai sebagai SD tempat penelitian PTK. SDN Salatiga 06 sebagai SDN percontohan se-Salatiga menerapkan Kurikulum 2013 sejak awal dengan kondisi kelas paralel dari kelas I sampai kelas VI berbasis tematik integratif yaitu antar mata pelajaran satu dengan mata pelajaran lainnya saling berhubungan dengan memadukan tema yang sama. Dalam penerapan Kurikulum baru yang selalu mengalami perubahan atau revisi ke arah yang lebih baik. Menurut hasil observasi dan wawancara kami pada kelas 2 di SDN Salatiga 06 memiliki beberapa kendala dalam penerapan Kurikulum 2013, diantaranya dengan adanya Buku Guru dan Buku Siswa yang telah beredar dengan Kurikulum 2013 dan telah direvisi sehingga lebih memudahkan guru serta membuat guru masih terlalu mengandalkan buku yang telah disediakan tanpa mengembangkan esensi yang ada didalamnya. Termuatnya model dan langkah-langkah pembelajaran yang lebih praktis di Buku Guru, guru lebih cenderung terpancang mengikuti apa yang telah ada dan telah ditetapkan bagaimana seharusnya jalannya pembelajaran.

Selain itu, keterpaduan antarmuatan yang terikat dalam satu tema pembelajaran terkadang masih terlihat terpisah-pisah dan penguasaan materi yang diterima oleh siswa kurang mendalam. Padahal dengan kurikulum yang sebelumnya, pembelajaran yang diberikan bisa secara urut disampaikan dan kontinu dipelajari sehingga materi yang didapat lebih banyak. Namun, dengan kendala yang ada, banyak yang didapat dari perbaikan kurikulum yang telah ditetapkan oleh pemerintah. Salah satunya, harapan dari pemerintah itu sendiri sangatlah tinggi untuk mencapai pendidikan yang berkualitas seperti negaranegara lain dapat diwujudkan sedikit demi sedikit. Untuk itu, pemerintah juga sangat mengharapkan adanya perubahan-perubahan yang positif dalam meningkatkan pendidikan Indonesia dengan cara mengembangkan perangkat pembelajaran melalui pendekatan konstruktivisme yang didukung dengan $5 \mathrm{M}$ yaitu dimulai dari mengamati, menanya, menalar, menganalisis dan mengomunikasikan. Oleh karena itu, perlu dilakukan inovasi dalam proses pembelajaran yang berlangsung, yaitu dengan menerapkan model pembelajaran dan pemilihan media pembelajaran yang tepat, yang ditujukan untuk merangsang minat siswa dalam mengikuti kegiatan belajar mengajar, meningkatkan keaktifan siswa dan memaksimalkan pencapaian hasil belajar siswa. Salah satu inovasi pembelajaran yang dapat dilakukan oleh guru adalah dengan menerapkan model pembelajaran VAK dengan media tongkat tokoh.

Menurut Shoimin (2014: 226) "Model pembelajaran VAK adalah model pembelajaran yang mengoptimalkan ketiga modalitas belajar tersebut untuk menjadikan si belajar merasa nyaman". Model pembelajaran ini merupakan model pembelajaran dengan gaya belajar multisensorik dimana guru tidak hanya mendorong siswa untuk menggunakan satu modalitas saja, namun berusaha mengombinasikan semua modalitas tersebut untuk memberikan kemampuan yang lebih besar dan menutupi kekurangan yang dimiliki masing-masing siswa. (Huda, 2013: 289). Media benda konkret digunakan sebagai sarana untuk mem-permudah guru dalam menyampaikan materi pembelajaran. Anitah (2008: 25) menyebutkan bahwa media realia (objek) adalah benda yang sebenarnya dalam bentuk utuh. Pemilihan media konkret dikarenakan media konkret dapat memberikan pengalaman langsung pada anak, karena anak dapat mengamati secara langsung dari arah pandang mana saja. Benda konkret itu berupa media tongkat tokoh dalam menyampaikan materi mengenai hidup rukun dalam dongeng dan pecahan. 
Pendekatan yang digunakan akan mendukung jalannya Kurikulum 2013 dengan keterpaduan yang sejalan dan pergantian antarmuatan pelajaran tidak terlihat. Agar tujuan yang diharapkan dapat tercapai, maka dilakukan proses peningkatan agar kendala atau permasalahan yang ada tidak berakibat berkelanjutan. Pada pembelajaran tematik kurikulum 2013 ini, dapat diberikan suatu usaha pemakaian model untuk meningkatkan proses dan hasil belajar siswanya. Model yang digunakan untuk mengatasi permasalahan tersebut yaitu model pembelajaran Fleming. Rusman (2013: 133) mengemukakan bahwa model pembelajaran VAK adalah model pembelajaran yang menekankan bahwa belajar haruslah memanfaatkan alat indra yang dimiliki siswa. Pembelajaran dengan model pembelajaran VAK adalah suatu pembelajaran yang memanfaatkan gaya belajar setiap individu dengan tujuan agar semua kebiasaan belajar siswa akan terpenuhi. Menurut Ngalimun (2013: 138) model pembelajaran ini menganggap bahwa pembelajaran akan efektif dengan memperhatikan potensi siswa yaitu manfaatkan potensi siswa yang dimiliki dengan melatih dan mengembangkannya. Istilah tersebut sama halnya dengan istilah pada SAVI, dengan somatic ekuivalen dengan kinesthetic. Jadi model pembelajaran VAK adalah model pembelajaran yang mengkombinasikan ketiga gaya belajar (melihat, mendengar, dan bergerak) setiap individu dengan cara memanfaatkan potensi yang telah dimiliki dengan melatih dan mengembangkannya, agar semua kebiasaan belajar siswa terpenuhi. Deporter, et.al. (2003: 112) mengemukakan bahwa model pembelajaran VAK adalah model pembelajaran yang menjadikan siswa mudah memahami materi yang diajarkan guru karena mengoptimalkan ketiga modalitas belajar tersebut. Pembelajaran dengan model ini mementingkan pengalaman belajar secara langsung dan menyenangkan bagi siswa. Pengalaman belajar secara langsung dengan mengingat (visual), belajar dengan mendengar (auditory), dan belajar dengan gerak dan emosi (kinestethic). Pembelajaran dilaksanakan dengan memanfaatkan potensi siswa yang telah dimilikinya dengan melatih dan mengembangkannya. Pada Tema Kebersamaan guru menggunakan model VAK ini berbantu media tongkat tokoh untuk lebih menekankan dan memacu visual, auditori dan kinestetik pada anak.

Beberapa penelitian terkait tentang pembelajaran yang menerapkan model pembelajaran VAK telah berhasil dilakukan. Salah satunya penelitian yang dilakukan oleh David Marshall Forno (2015: 2) dengan judul "Penggambaran Karakter pada Tokoh Utama dalam Film "Maleficent". Hasil nilai yang semula belum diterapkan penggambaran karakter pada tokoh utama ini rata-rata $50 \%$ masih di bawah nilai KKM yang telah ditentukan. Siklus I sudah mengalami peningkatan walaupun belum signifikan yaitu 65,15 , hasil inipun masih dibawah KKM sehingga dengan pertimbangan diadakan siklus II yang hasilnya 81,15. Dari hasil antara siklus yang meningkat dan diakhiri siklus II dengan nilai yang sudah di atas KKM maka PTK yang dilakukan peneliti ini dikatakan berhasil. Penelitian oleh Saputra (2014) menunjukkan bahwa model pembelajaran VAK berbantuan media audio visual dapat meningkatkan hasil belajar IPA siswa kelas IVB SD No. 2 Banyuasri.

Penelitian oleh Rosyidah (2010), menunjukkan bahwa penerapan model pembelajaran VAK berbantuan media video animasi dapat meningkatkan hasil belajar IPS pada siswa kelas VIB semester I di SD Laboratorium tahun pelajaran 2011/2012. penelitian yang dilakukan oleh Erlina (2011). Hasil penelitian tersebut menunjukkan bahwa implementasi model pembelajaran VAK dapat meningkatkan aktivitas dan prestasi belajar matematika pada siswa kelas IV semester genap SD No. 1 Petandakan Kecamatan Buleleng. Pada siklus I, aktivitas belajar siswa adalah 79, 14\% tergolong cukup aktif.

Berdasarkan uraian permasalahan di atas, maka penulis tertarik untuk mengadakan Penelitian Tindakan Kelas (PTK) secara kolaboratif dengan penerapan model pembelajaran VAK dengan media benda konkret berupa tongkat tokoh dalam peningkatan aktivitas dan hasil belajar Tema Kebersamaan Kelas 2 SD Negeri Salatiga 06 Semester II Tahun Ajaran 2017/2018.

\section{Metode}

Penelitian Tindakan Kelas ini dilaksanakan di kelas 2 SD Negeri Salatiga 06 Kota Salatiga. Lokasi SD Negeri Salatiga 06 adalah di Jalan Kartini No. 26, Salatiga, Sidorejo, Kota Salatiga. Sebagai sekolah percontohan, SD Negeri Salatiga 06 mempunyai fasilitas yang mendukung proses pembelajaran.

Penelitian Tindakan Kelas dilaksanakan pada semester 2 tahun pelajaran 2017/2018 pada Tema Kebersamaan. Sikus I terdiri dari tiga kali pertemuan yang dilaksanakan pada tanggal 22 Maret, 23 Maret, dan 24 Maret untuk pelaksanaan evaluasi. Siklus II juga terdiri dari dua kali pertemuan yang dilaksanakan pada tanggal 5 April, 6 April, dan 7 April untuk pelaksanaan evaluasi. Jenis penelitian yang dipilih adalah Penelitian Tindakan Kelas (PTK) sebagai upaya untuk meningkatkan aktivitas dan hasil belajar siswa kelas 2. Penelitian dilakukan dengan model pembelajaran VAK berbantu media tongkat tokoh merupakan penyajian materi pelajaran berbasis tematik integratif yang akan didukung dengan tiga gaya belajar dengan empat tahap yang harus ditempuh yaitu tahap persiapan, tahap penyampaian, tahap 
pelatihan, dan tahap penampilan hasil. Persoalan yang ada harus dipecahan oleh siswanya dengan bimbingan guru dengan mengedepankan scientific.

Jenis data yang digunakan pada PTK ini adalah jenis data kuantitatif dan kualitatif. Sumber data yang digunakan pada penelitian ini antara lain adalah guru, siswa, data dokumen, catatan lapangan, dan jurnal. Teknik pengumpulan datanya menggunakan metode observasi, dokumentasi, dan tes. Adapun Instrumen penelitian yang digunakan adalah observasi, tes, dan dokumentasi. Sebelum instrumen digunakan, harus di uji terlebih dahulu yaitu uji validitas, uji reliabilitas setelah dilakukan uji coba instrumen yang dilaksanakan pada kelas 3. Uji coba dilakukan di kelas 3 karena materi yang diberikan adalah materi yang sudah diajarkan pada anak-anak kelas 3, sehingga dapat mengetahui soal-soal mana yang dapat dipaki atau digunakan untuk uji selanjutnya di kelas 2 dengan tingkat ke validan soal yang baik. Penghitungannya menggunakan SPSS versi 21. Untuk uji reliabilitas digunakan metode Alpha (Cronbach's). Selain itu, uji instrumen dengan menguji taraf kesukaran. Indikator keberhasilan meliputi Indikator Kinerja dan Indokator Hasil Tindakan. Teknik analisis data, untuk yang kuantitatif dilakukan seacara deskriptif komparatif yaitu membandingkan hasil belajar berdasarkan nilai tes pada setiap siklusnya. Sedangkan analisis data kualitatif dilakukan dengan cara analisis deskriptif berdasarkan hasil observasi aktivitas kinerja guru dan observasi aktivitas siswa.

\section{Hasil dan Pembahasan}

Kegiatan pembelajaran dalam penelitian ini dilaksanakan sesuai dengan langkah-langkah penerapan model VAK dengan media tongkat tokoh, yaitu: 1) tahap persiapan, 2) tahap penyampaian, 3) tahap pelatihan, dan 4) tahap penyampaian hasil. Penelitian dilakukan karena muncul permasalahan yang terkait dengan hasil belajar yang rendah pada Tema 7 Kebersamaan. Daya serap siswa terhadap materi dan rasa ingin tahu yang rendah dalam mengikuti setiap proses pembelajaran merupakan faktor dari siswa yang menyebabkan rendahnya perolehan hasil belajar Tema 7 Kebersamaan. Minat dan rasa ingin tahu siswa yang rendah dalam mengikuti kegiatan pembelajaran dapat terlihat dari sikap siswa yang tidak memperhatikan guru saat menyampaikan materi. Keadaan ini membuat guru mendominasi di setiap proses pembelajaran karena guru selalu memberikan instruksi yang harus dilakukan oleh siswa. Selanjutnya, penggunaan media sangat diperlukan guru untuk menyampaikan materi sehingga pengetahuan yang siswa terima tidak hanya pengetahuan instan dari guru melainkan siswa juga bisa melakukan aktivitas pembelajaran yang lebih bermakna dengan adanya media pembelajaran.

Tabel 1. Hasil Observasi terhadap Kinerja Guru dan Respon Siswa dalam Penerapan Model VAK Berbantu Media Tongkat Tokoh

\begin{tabular}{|c|c|c|c|c|c|c|c|}
\hline \multirow[b]{2}{*}{ No. } & \multirow[b]{2}{*}{ Kategori } & \multicolumn{2}{|r|}{ Pra Siklus } & \multicolumn{2}{|r|}{ Siklus I } & \multicolumn{2}{|r|}{ Siklus II } \\
\hline & & Rata-Rata & $\begin{array}{l}\text { Persentase } \\
\text { Ketuntasan } \\
(\%)\end{array}$ & $\begin{array}{l}\text { Rata- } \\
\text { Rata }\end{array}$ & $\begin{array}{l}\text { Persentase } \\
\text { Ketuntasan } \\
(\%)\end{array}$ & $\begin{array}{l}\text { Rata- } \\
\text { Rata }\end{array}$ & $\begin{array}{l}\text { Persentase } \\
\text { Ketuntasan } \\
(\%)\end{array}$ \\
\hline 1. & $\begin{array}{l}\text { Aktivitas } \\
\text { Guru }\end{array}$ & 3,3 & 84 & $2^{3,}$ & 80 & $6^{3,6}$ & 91,62 \\
\hline 2. & $\begin{array}{l}\text { Aktivitas } \\
\text { Siswa }\end{array}$ & 3,1 & 72 & $91^{2,}$ & 71,87 & $6^{3,5}$ & 89 \\
\hline
\end{tabular}

Tabel 2. Hasil Belajar Siswa

\begin{tabular}{|c|c|c|c|c|c|c|c|}
\hline \multirow[b]{2}{*}{ No. } & \multirow[b]{2}{*}{ Kategori } & \multicolumn{2}{|c|}{ Pra Siklus } & \multicolumn{2}{|r|}{ Siklus I } & \multicolumn{2}{|r|}{ Siklus II } \\
\hline & & $\begin{array}{l}\text { Banyak } \\
\text { Peserta } \\
\text { Didik }\end{array}$ & $\begin{array}{l}\text { Persentase } \\
\text { Ketuntasan } \\
(\%)\end{array}$ & $\begin{array}{l}\text { Banyak } \\
\text { Peserta Didik }\end{array}$ & $\begin{array}{l}\text { Persentase } \\
\text { Ketuntasan } \\
(\%)\end{array}$ & $\begin{array}{l}\text { Banyak } \\
\text { Peserta } \\
\text { Didik }\end{array}$ & $\begin{array}{l}\text { Persentase } \\
\text { Ketuntasan } \\
(\%)\end{array}$ \\
\hline 1. & Tuntas & 24 & 75 & 24 & 72,50 & 27 & 83,50 \\
\hline 2. & $\begin{array}{l}\text { Tidak } \\
\text { Tuntas }\end{array}$ & 8 & 25 & 6 & 27,50 & 3 & 16,50 \\
\hline
\end{tabular}

Data hasil observasi terhadap kinerja guru dan respon siswa dalam selama pembelajaran berlangsung dengan menerapkan model $V A K$ dengan media tongkat tokoh sebagai berikut: Pada penelitian ini dikatakan berhasil apabila sekurang-kurangnya $80 \%$ siswa memperoleh nilai $\geq 75$. Hasil penelitian menunjukkan : (1) Skor aktivitas pra siklus di kelas 3 sebesar 72\% dengan nilai rata-rata 73,50 
dan skor ketuntasan belajar siswa pra siklus sebesar 75\% dengan nilai rata-rata 76,50; (2) Ketuntasan belajar siswa pada siklus I sebesar 72,50\% dengan nilai rata-rata 78,15 dan pada siklus II sebesar 83,50\% dengan nilai rata-rata 85,25 (3) Skor aktivitas siswa pada siklus I sebesar 70\% dan pada siklus II sebesar 82,50\%. Dari data tersebut di atas jelas menunjukkan bahwa pada siklus I hasil belajar belum sesuai harapan yang berarti indikator keberhasilan belum tercapai sedangkan pada siklus II hasil belajar sudah sesuai harapan yang berarti indikator keberhasilan sudah tercapai.

Berdasarkan data hasil penelitian pada siklus I dan siklus II menunjukkan bahwa model pembelajaran VAK (Visualization, Auditory, Kinestetic) dapat meningkatkan aktivitas belajar dan hasil belajar siswa. Adapun keunggulan dari model pembelajaran VAK yaitu, pembelajaran menjadi lebih efektif karena dapat mengkombinasikan ketiga gaya belajar, mampu melatih dan mengembangkan potensi siswa yang telah dimiliki oleh pribadi masing-masing, memberikan pengalaman langsung kepada siswa, mampu melibatkan siswa secara maksimal dalam menemukan dan memahami suatu konsep melalui kegiatan fisik seperti demonstrasi, percobaan, observasi, dan diskusi aktif dan mampu menjangkau setiap gaya belajar siswa (Colin, 2002:118).

Proses pembelajaran dengan model pembelajaran VAK memberikan lebih banyak waktu kepada siswa untuk lebih aktif selama pembelajaran berlangsung sehingga guru lebih berfungsi sebagai fasilltator pembelajaran dan motivator bagi siswa dalam mengembangkan pengetahuan, keterampilan, dan sikapsikap. Selain itu dapat membuat para siswa untuk merasa percaya diri sehingga mengurangi rasa takut salah jika mengerjakan tugas dari guru dan siswa lebih aktif berdiskusi dengan kelompok dan mengerjakan LAS, yang berakibat meningkatkan aktivitas siswa selama proses pembelajaran juga dapat menyebabkan pemahaman materi yang diberikan guru semakin mudah untuk dipahami siswa sehingga hasil belajar metematika siswapun mengalami peningkatan.

Beberapa penelitian yang sejalan tentang penerapan model pembelajaran VAK berbantu media tongkat tokoh telah banyak dipublikasikan. Hasil Penelitian yang dilakukan Junaidin (2014) dengan judul "Penggunaan Media Boneka Tongkat Untuk Meningkatkan Keterampilan Menyimak Dongeng Siswa Kelas 2 SDN Mojolangu 05 Malang". Hasil penelitian menunjukkan bahwa penerapan media boneka tongkat berturut-turut dari siklus 1 dan siklus 2 memperoleh nilai 81,5 dan 83. Aktivitas belajar siswa dalam belajar Bahasa Indonesia meningkat ketika diterapkan media boneka tongkat, pada siklus 1 dan siklus 2 memperoleh nilai rata-rata 76 dan 85. Hasil belajar siswa meningkat setelah diterapkan media boneka tongkat nilai rata-rata hasil belajar secara klasikal siklus 1 yaitu 78 meningkat menjadi 87 pada siklus 2 .

Siti Ghufira (2016) Pengaruh Model Pembelajaran Visual Auditory Kinesthetic (VAK) Terhadap Aktivitas Belajar Tematik Peserta Didik Kelas 2 SD Negeri 1 Haduyang Tahun Pelajaran 2015/2016". Hasil penelitian menunjukkan bahwa melalui model pembelajaran VAK dapat meningkatkan aktivitas belajar tematik pada siswa kelas 2 SD Negeri Haduyang Tahun Pelajaran 2015/2016. Aktivitas belajar siswa dari siklus I ke siklus II terdapat peningkatan dari jumlah 30 siswa yang tuntas siklus I 20 siswa yaitu 66,67 \% menjadi 28 siswa yaitu 93,33\%.

Andea Nurellah, Regina Lichteria Panjaitan, Maulana (2016: 1) dengan judul "Penerapan Model Pembelajaran Visual, Auditorial, dan Kinestetik Untuk Meningkatkan Hasil Belajar Siswa Sekolah Dasar”. Hasil penelitian menunjukkan bahwa melalui model pembelajaran VAK dapat meningkatkan hasil belajar siswa SD. Hasil belajar meningkat signifikan dari siklus I ke siklus II yaitu dari 73,33 menjadi 86,15, sehingga penelitian ini dikatakan berhasil.

Menurut Haryadi (2010: 5) pembelajaran VAK dipusatkan pada cara belajar siswa dengan langkah yang sistematis yaitu belajar melalui melihat sesuatu, belajar melalui mendengar sesuatu, dan belajar melalui aktivitas fisik dan keterlibatan langsung. Pada penelitian yang dilakukan Gilakjani (2011) menunjukkan bahwa 50\% siswa menggunakan gaya belajar visual, 35\% siswa menggunakan gaya belajar auditori, dan 15\% siswa menggunakan gaya belajar kinestetik. Sedangkan pada penelitian yang dilakukan Putri (2010) menyatakan bahwa model pembelajaran VAK memberikan kontribusi yang signifikan terhadap hasil belajar dan kreativitas siswa. Dari hasil penelitiannya, efektivitas pembelajaran kimia menggunakan KIT berorientasi VAK sebesar 87,50\% terhadap kognitif siswa.

Dengan demikian dapat disimpulkan bahwa model pembelajaran VAK berbantu media tongkat tokoh dapat digunakan dan diterapkan pada kelas 2 dengan Tema Kebersamaan materi dongeng fabel dan pecahan. Penerapan model pembelajaran VAK berbantu media tongkat tokoh dapat meningkatkan aktivitas dan hasil belajar siswa menjadi sarana penyampaian materi ajar hingga mampu memenuhi ketercapaian tujuan pembelajaran.

\section{Simpulan Dan Saran}

Berdasarkan hasil penelitian dapat disimpulkan bahwa penerapan model VAK dengan media tongkat tokoh dapat meningkatkan aktivitas dan hasil belajar Tema Kebersamaan pada siswa kelas 2 SD 
Negeri Salatiga 06 tahun ajaran 2017/2018. Hasil observasi dari penerapan model VAK dengan media tongkat tokoh terhadap kinerja guru dan respon siswa dalam selama pembelajaran berlangsung dengan menerapkan model VAK dengan media benda konkret sebagai berikut: Pada penelitian ini dikatakan berhasil apabila sekurang-kurangnya $80 \%$ siswa memperoleh nilai $\geq 75$. Hasil penelitian menunjukkan : (1) Skor aktivitas pra siklus di kelas 3 sebesar $72 \%$ dengan nilai rata-rata 73,50 dan skor ketuntasan belajar siswa pra siklus sebesar 75\% dengan nilai rata-rata 76,50; (2) Skor aktivitas siswa pada siklus I sebesar 70\% dan pada siklus II sebesar 82,50\%; (3) Ketuntasan belajar siswa pada siklus I sebesar $72,50 \%$ dengan nilai rata-rata 78,15 dan pada siklus II sebesar $83,50 \%$ dengan nilai rata-rata 85,25 . Dari data tersebut di atas jelas menunjukkan bahwa pada siklus I hasil belajar belum sesuai harapan yang berarti indikator keberhasilan belum tercapai sedangkan pada siklus II hasil belajar sudah sesuai harapan yang berarti indikator keberhasilan sudah tercapai.

Berdasarkan simpulan yang telah diuraikan, maka diajukan saran sebagai berikut: 1) bagi guru, hendaknya menerapkan model pembelajaran serta media yang sesuai dengan karakteristik siswa, salah satunya adalah penerapan model VAK dengan media tongkat tokoh, sehingga pembelajaran berjalan lebih efektif dan hasil belajar yang di-capai siswa lebih maksimal; 2) bagi siswa, siswa harus lebih aktif, disiplin, dan meningkatkan keberanian dan percaya diri siswa untuk menyampaikan pendapat mereka selama proses pem-belajaran berlangsung; 3) bagi sekolah, hendaknya sekolah meningkatkan kompetensi pendidik dengan melaksanakan pelatihan bagi guru dan sekolah menyediakan fasilitas pembelajaran yang lebih memadai agar dapat melaksanakan inovasi dalam pembelajaran; dan 4) bagi peneliti lain, hendaknya lebih kretif dan variatif dalam menciptakan pembelajaran yang berkualitas dan memberikan sumbangan ilmu yang lebih inovatif bagi pendidikan.

\section{Daftar Rujukan}

Anitah, S. (2008). Media Pembelajaran. Surakarta: LPP UNS dan UNS Press.

Arikunto, S., Suhardjono, \& Supandi. (2012). Penelitian Tindakan Kelas. Jakarta: PT Bumi Aksara.

David Marshall Forno. 2015. Jurnal E-Komunikasi Program Studi Ilmu Komunikasi Universitas Kristen Petra, Surabaya Penggambaran Karakter Pada Tokoh Utama Dalam Film "Maleficent". Surabaya

Ghufira, Siti. 2016. Jurnal Pengaruh Model Pembelajaran Visual Auditory Kinesthetic (VAK) Terhadap Aktivitas Belajar Tematik Peserta Didik Kelas 2 SD Negeri 1 Haduyang Tahun Pelajaran 2015/2016

Hosnan. 2014. Pendekatan Saintifik dan Kontekstual dalam Pembelajaran Abad 21. Jakarta: Ghalia Indonesia.

Huda, M. (2014). Model-Model Pengajaran dan Pembelajaran: Isu Metodis dan Paradigmatis. Yogyakarta: Pustaka Pelajar.

I Ketut Dibia, I Putu Mas Dewantara, I Wayan Widiana. (2017). Jurnal Pemberdayaan Teknik Bercerita Berbasis Budaya Bali Dalam Pembelajaran Keterampilan Menulis Karangan Pribadi Siswa Kelas V SD Mutiara Singaraja. Universitas Pendididkan Ganesha: Journal of Education Research and Evaluation.

Jihad, A. dan Abdul Haris. 2012. Evaluasi Pembelajaran. Yogyakarta: Multi Presindo.

Joyce, Bruce, Marsha Weil dan Emily Calhoun. 2009. Models of Teaching (Model-model Pengajaran). Jakarta: Pustaka Pelajar.

Junaidin. 2014. Jurnal Penggunaan Media Boneka Tongkat Untuk Meningkatkan Keterampilan Menyimak Dongeng Siswa Kelas 2 SDN Mojolangu 05 Malang. Malang

Kemendikbud. 2014. Implementasi Kurikulum 2013. Jakarta: Kemendibud.

Lupita Cristin Katuuk. 2015. Jurnal Skripsi Analisis Perbandingan Struktur Dongeng 'Der Fuchs Und Das Pferd' Dan 'Die Bienenkönigin' Karya Brüder Grimm. Universitas Sam Ratulangi Fakultas Ilmu Budaya Manado. Manado 
Mulyasa. 2015. Pengembangan dan Implementasi Kurikulum 2013. Bandung: PT Remaja Rosdakarya.

Nurellah, Andea. Regina Lichteria Panjaitan, \& Maulana. (2016: 1). Jurnal Penerapan Model Pembelajaran Visual, Auditorial, dan Kinestetik Untuk Meningkatkan Hasil Belajar Siswa SD.

Permendikbud No. 24 Tahun 2016 tentang Kompetensi Inti dan Kompetensi Dasar.

Permendikbud No. 21 Tahun 2016 tentang Standar Isi.

Purwanto. (2013). Evaluasi Hasil Belajar. Yogyakarta: Pustaka Pelajar.

Sani, Ridwan Abdullah. 2014. Pembelajaran Saintifik untuk Implementasi Kurikulum 2013. Jakarta: Bumi Aksara.

Saputra, Agus Bayu, L Pt. Putrini Mahadewi, Gd. Raga. 2014. Implementasi Model Pembelajaran Vak Berbantuan Media Audio Visual Untuk Meningkatkan Hasil Belajar Ipa Siswa Kelas IVb Sd No. 2 Banyuasri. e-Journal MIMBAR PGSD Universitas Pendidikan Ganesha Jurusan PGSD Vol: 2 No: 1

Shoimin, A. (2014). 68 Model Pembelajaran Inovatif dalam Kurikulum 2013. Yogyakarta: Ar-Ruzz Media

Suarsana, IM. (2013). Jurnal Pengembangan E-Modul Berorientasi Pemecahan Masalah untuk Meningkatkan Keterampian Berpikir Kritis Mahasiswa. Universitas Pendidikan Ganesha: Jurnal Pendidikan Indonesia.

Suarsana, IM \& I Gusti Ngurah Pujawan. (2017). Jurnal Pendidikan dan Latihan Pembelajaran Pecahan Bagi Guru-Guru Sekolah Dasar Gugus V Kecamatan Kubu. Universitas Pendidikan Ganesha: Jurnal Widya Laksana

Sugiyono. (2015). Metode Penelitian Pendidikan: Pendekatan Kuantitatif, Kualitatif, dan R \& D. Bandung: Alfabeta.

Sundayana, Rostina. 2015. Media dan Alat Peraga dalam Pembelajaran Matematika. Bandung: Alfabeta.

Suprijono, Agus. 2012. Cooperative Learning. Yogyakarta: Pustaka Pelajar.

Susanto, Ahmad. 2013. Teori Belajar dan Pembelajaran di Sekolah Dasar. Jakarta: Kencana.

UU Nomor 20 Tahun 2003 tentang Sistem Pendidikan Nasional 